\title{
The Effect of Public Health Intervention on the Knowledge of the Hazards of Smoking in Students
}

\author{
Sulaemana Engkeng*, Maureen Irinne Punuh, Afnal Asrifuddin \\ Faculty of Public Health, University of Sam Ratulangi, Manado, Indonesia \\ Email address: \\ sulaemanaengkeng@unsrat.ac.id (S. Engkeng), punuhmaureen@unsrat.ac.id (M. I. Punuh), afnal.asrifuddin@unsrat.ac.id (A. Asrifuddin) \\ ${ }^{*}$ Corresponding author
}

\section{To cite this article:}

Sulaemana Engkeng, Maureen Irinne Punuh, Afnal Asrifuddin. The Effect of Public Health Intervention on the Knowledge of the Hazards of Smoking in Students. Journal of Health and Environmental Research. Vol. 7, No. 4, 2021, pp. 181-184. doi: 10.11648/j.jher.20210704.12

Received: September 8, 2021; Accepted: September 29, 2021; Published: October 12, 2021

\begin{abstract}
The national percentage of smoking every day for population $>10$ years is $23.7 \%$. Most of the students in Kotamobagu were smokers, according to the initial survey were carried out by looking directly at the surroundings of Kotamobagu 1 Public Senior High School. Several students smoked around the school. Based on this, it is necessary to research public health interventions as an effort to prevent the dangers of smoking in students through counselling in increasing knowledge about the dangers of smoking. The research objective was the effect of public health interventions on knowledge about the dangers of smoking in students at Kotamobagu 1 Public Senior High School. The output target in this study is that after this research, it is hoped that the effect of public health interventions on knowledge about the dangers of smoking will be known. The research methodology used was experimental research with a quasi-experimental approach with one group pre-test and post-test. The population in this study were all students in class XI totalling 391 . The total sample was 80 students. The statistical test results obtained p-value $=0.000$, compared with the coefficient alpha $(\alpha)=0.05(0.000)<0.05$, thus Ho is rejected and $\mathrm{Ha}$ is accepted which can be concluded that the average knowledge before and after the extension is different. It can be stated that counselling affects students' knowledge about the dangers of smoking.
\end{abstract}

Keywords: Intervention, Knowledge, The Dangers of Smoking

\section{Introduction}

Public health intervention is an effort to increase public awareness to make efforts to prevent disease through efforts to change behaviour [1]. Lifestyle changes and adherence to medication are major obstacles. The dangers of smoking have been shown to cause various chronic diseases such as coronary heart disease, lung cancer, obstructive pulmonary disease and stroke. In fact, these diseases are only part of the dangers of smoking to health.

Data from the World Health Organization (WHO) and Research for International Tobacco Control found that 1 death caused by tobacco worldwide occurs every 6 seconds [2]. In 2005 , there were 5.4 million deaths from tobacco and during the 20th century, there were as many as 100 million deaths from tobacco. If this is allowed, there will be 8 million deaths in 2030 and it is estimated that there will be 1 billion deaths due to tobacco during the 21 st century [3].

Cigarettes with low nicotine levels, but it is not true that cigarettes that are low in nicotine will prevent smokers from the dangers of nicotine. The argument that cigarettes with low nicotine levels are harmless is just a justification for the action. Smoking is an unhealthy lifestyle. Every time you inhale cigarette smoke, whether intentionally or accidentally, you also inhale thousands of toxins. One thing if you want to live healthily and don't want to experience health problems, there is no compromise, namely to stop and stay away from cigarettes [4].

Cigarettes with low nicotine levels, but it is not true that cigarettes that are low in nicotine will prevent smokers from the dangers of nicotine. The argument that cigarettes with low nicotine levels are harmless is just a justification for the action. Smoking is an unhealthy lifestyle. Every time you inhale cigarette smoke, whether intentionally or accidentally, you also inhale thousands of toxins. One thing if you want to live healthily and don't want to experience health problems, there is no compromise, namely to stop and stay away from smoking. 
The content in cigarettes contains approximately 4000 chemical substances, including nicotine, which is carcinogenic. Knowledge of cognitive is a very important domain for the formation of one's actions (overt behaviour). Experience and research have shown that behaviour based on knowledge will be more lasting than behaviour not based on knowledge. Measurement of knowledge can be done by interview or questionnaire that asks about the content of the material to be measured from research subjects or students [5].

Ministry of Health data shows that the prevalence of adolescents aged 16-19 years who smoke has increased 3 times from $7.1 \%$ in 1995 to $20.5 \%$ in 2014 . More than a third or 36.3 per cent of Indonesia's population is currently smokers Even 20\% of adolescents aged 13-15 years are smokers. Currently, male adolescents who smoke are increasing. Data in 2016 shows an increase in the number of male adolescent smokers reaching 58.8\%, the smoking habit in Indonesia kills at least 235 thousand people every year [6].

The prevalence of smoking in Indonesia is high, especially for men who are more likely to smoke than women. The percentage of smokers over 15 years of age is $33.8 \%$. The percentage of total male smokers was $62.9 \%$ and the total percentage of female smokers was $4.8 \%$. This increase in the number of smokers has been accompanied by an increase in diseases caused by smoking [7].

The national percentage of smoking every day for people aged $>10$ years is $23.7 \%$, namely West Sumatra, Riau, Jambi, South Sumatra, Bengkulu, Lampung, Bangka Belitung, West Java, Central Java, Yogyakarta, East Java, Banten, Nusa Tenggara. West, North Sulawesi, Central Sulawesi, Gorontalo and North Maluku [7]. Most of the students in Kotamobagu were smokers. The results of the initial survey were carried out by looking directly around the school environment of SMA Negeri 1 Kotamobagu. Several students smoked around the school.

Based on this, it is necessary to research public health interventions as an effort to prevent the dangers of smoking in students through counselling in increasing knowledge about the dangers of smoking. The research objective was the effect of public health interventions on knowledge about the dangers of smoking in students at Kotamobagu 1 Public Senior High School. The output target in this study is that after this research, it is expected that the effect of public health interventions on knowledge about the dangers of smoking is known.

The purpose of this study was to analyze the effect of public health interventions on knowledge about the dangers of smoking in students at Kotamobagu 1 State Senior High School.

\section{Method}

The type of research used is a quantitative research using a quasi-experimental approach in one group pre-test and post-test [8]. To find out whether there is an influence, a pre-test (01) is carried out on students, and followed by interventions on students. After some time, a Post-test (02) was carried out on students. This research was conducted in July-September 2020. The population in this study were all students of class XI at SMA Negeri 1 Kotamobagu with a total of 391 students The sampling used in this study was the stratified random sampling method, namely the sampling method of the population. With different or heterogeneous characteristics using the Slovin formula as many as 80 students. The research instrument used a questionnaire. The data analysis used was univariate and bivariate analysis using statistical tests, namely the t-paired t-test [9]. This method illustrates that students' knowledge and attitudes are measured before health education (pre-test scores) and the knowledge test after health education (Post-test scores) is measured and then the scores of each student are compared between before counselling (Pre-test) and after counselling (Post-test).

\section{Hasil}

The characteristics of students at Kotamobagu 1 Public Senior High School are Age, Class, Knowledge. How to provide pre-test and post-test interventions after being given counselling.

Table 1. Characteristics of students based on age in Public Senior High School 1 Kotamobagu.

\begin{tabular}{lll}
\hline Age & Frequency & Percentage \\
\hline 16 & 11 & 13.75 \\
17 & 69 & 86.25 \\
Total & 80 & 100 \\
\hline
\end{tabular}

In Table 1, the age characteristics represent the age of the students when the study was conducted. The results showed that the majority of students in this study were 17 years old, as many as 69 students $(86.25 \%)$, while the remaining 16 years old were 11 students $(13.75 \%)$. It can be concluded that most of the students are included in the adolescent age category as disclosed by WHO (2017) that adolescents are individuals, both women and men who are between the ages of 10-20 years [10].

Table 2. Characteristics of students by class in Public Senior High School 1 Kotamobagu.

\begin{tabular}{lll}
\hline Class & Frequency & Percentage \\
\hline XI IPA A & 32 & 40 \\
XI IPA B & 26 & 32.5 \\
XI IPA C & 22 & 27.5 \\
Total & 80 & 100 \\
\hline
\end{tabular}

In table 2 the characteristics of students based on a class show that 32 students came from class XI IPA A (40\%), class XI IPA B with 26 students (32.5\%), while others from class XI IPA $\mathrm{C}$ were as many as 26 students. 22 students $(27.5 \%)$. All students are students from the science department of class XI, however, there is no difference in perceptions between classes $\mathrm{A}, \mathrm{B}$, and $\mathrm{C}$. 
Table 3. Frequency distribution of students' knowledge levels about the dangers of smoking before and after receiving counselling at State Senior High School 1 Kotamobagu.

\begin{tabular}{llllll}
\hline \multirow{2}{*}{ Knowledge } & \multicolumn{2}{l}{ Before (Pre-Test) } & \multicolumn{2}{c}{ After (Post-Test) } & \multirow{2}{*}{ P-Value } \\
\cline { 2 - 5 } & $\mathbf{n}$ & $\mathbf{\%}$ & $\mathbf{n}$ & $\mathbf{\%}$ & \\
\hline Good & 68 & 85 & 78 & 97.5 & \multirow{2}{*}{0.000} \\
Enough & 12 & 15 & 2 & 2.5 & \\
Total & 80 & 100 & 80 & 100 & \\
\hline
\end{tabular}

In table 3 , it can be seen that the level of knowledge of students about the dangers of smoking before getting counselling about the dangers of smoking in Kotamobagu Public Senior High School 1, the majority of students' knowledge levels in the good category were 68 students $(85 \%)$, while a small proportion of them was knowledgeable about the dangers. There were 12 students $(15 \%)$ who smoked before getting counselling. Statistical test results obtained $\mathrm{P}$-value $=0.000$, compared with the coefficient alpha $(\alpha)=0.05$, then the p-value $(0.000)<0.05$, thus Ho is rejected and $\mathrm{Ha}$ is accepted which can be concluded the average knowledge before and after counseling is different. It can be stated that counseling affects students' knowledge about the dangers of smoking.

\section{Discussion}

The level of knowledge of students about the dangers of smoking before getting counselling about smoking at Kotamobagu 1 Public Senior High School. The results of the pre-test research showed that the level of adolescent knowledge about the dangers of smoking was included in the good category as many as 68 students (85\%), sufficient category 12 students $(15 \%)$. The majority of respondents 'knowledge is sufficient and perceptions are less likely to be caused by a lack of memory in students' knowledge about the dangers of smoking. Knowledge or insight is very closely related to the information a person obtains, meaning that if someone gets more and better information from various media such as television, radio or newspapers, then it can increase one's knowledge as well as shape one's perception of the better. Thus it can be concluded that the higher a person's knowledge, the higher the level of one's accuracy towards the object of perception [11]. The results of this study are relevant to Gafar's research which states that there is an effect of providing health promotion through Facebook on knowledge about the dangers of smoking.

Another factor that affects the perceptions of students in the moderate category is the age of the respondent. It is known that the age of the respondents is mostly 17 years old as many as 69 students $(86.25 \%), 15$ years old as many as 11 students $(13.75 \%)$. One of them is that teenagers prefer to like solving problems they face together and tend to prefer their friends who have the same characteristics as themselves [12], at this age adolescents, also have the ability to more easily receive information.

Poor knowledge about smoking is caused by a culture that believes smoking can improve mood, inspire inspiration, reduce stress and reduce friends. This myth has developed in society and has become commonplace, smokers believe that smoking provides benefits even though smokers know that its effects are harmful to health. This means that cultural culture affects one's knowledge, which is by the opinion of Walgito (2010) that a person's cultural beliefs and personal values affect knowledge about smoking [11].

Differences in the level of perceptions before receiving counselling and after receiving counselling about the dangers of smoking in Kotamobagu 1 Public Senior High School. The results of the post-test in this study showed an increase compared to the pre-test results. The results of the study before being given counselling on smoking (pre-test) were obtained in good categories as many as 68 students (85\%), while the adequate category was 12 students $(15 \%)$. The results of the post-test or after being given counselling on smoking showed that there were 78 students $(97.5 \%)$ in the good category, while the adequate category was 2 students $(2.5 \%)$. The results of the study indicate the difference between before and after counselling, this can be seen in the average results before and after. The results of this study found that the perception after counselling was in a good category as much as $97.5 \%$, which means that the learning process in counselling can be said to be good. This assumption is by the theory of Walgito (2010) which states that the factors that affect knowledge, one of which is the learning process. The learning process is defined as the stages of changes in cognitive, affective, and psychomotor behaviour that occur within a person [11]. In this study, it was found that knowledge had changed from sufficient to mostly good perceptions.

Extension activities are one of the health education activities that can affect the way a person views and their environment, which are aimed at developing or improving certain abilities [13]. Based on this statement, it can be concluded that extension activities in the form of counselling can affect perspective, which means that the better the counselling activities held, the better one's knowledge tends to be. Changes in the knowledge of students are influenced by extension factors. The counselling carried out in this study can be said to be successful. The success of extension can be seen in the different mean results. Factors that influence the success of counselling is increasing perceptions can be seen from the time availability factor. This study gives students time to take part in counselling which in extension uses the media to convey information that can be understood by students well, wherewith online counselling students can directly contact the presenters more incentives without embarrassment if they are directly in class which can help students in solving problems related to the dangers of smoking.

\section{Conclusions}

The knowledge of students who are included in the good category before counseling is $85 \%$ and after counseling is $97.5 \%$, where it is known that there is an increase of $12.5 \%$ good knowledge. The $p$-value obtained is $0.00(p<0.05)$, so it can be concluded that the average knowledge before and after counseling is different. This shows that health interventions in 
the form of counseling can affect the increase in knowledge about the dangers of smoking. So it is suggested to Kotamobagu 1 Public Senior High School to be able to provide material about the dangers of smoking for students with the aim of improving the health of students. In addition, it is also recommended for other researchers to be able to conduct further research on the dangers of smoking in students.

\section{References}

[1] Machfoedz, I., \& Suryani, E. (2003). Pendidikan Kesehatan Bagian dari Promosi Kesehatan. Yogyakarta: Fitramaya.

[2] World Health Organization, \& Research for International Tobacco Control. (2008). WHO Report on the Global Tobacco Epidemic, 2008 the MPOWER Package. World Health Organization.

[3] Hutapea, C. E. Z., Rumayar, A. A., \& Maramis, F. R. R. (2017) Hubungan Antara Pengetahuan dan Sikap dengan Tindakan Terhadap Kebijakan Kawasan Tanpa Rokok Pada Siswa di SMP Kristen Tateli. KESMAS, 6 (3), 1-13.

[4] Lake, W. R. R., Hadi, S., \& Sutriningsih, A. (2017). Hubungan Komponen Perilaku (Pengetahuan, Sikap, Tindakan) Merokok Pada Mahasiswa. Nursing News: Jurnal Ilmiah Keperawatan, $2(3), 843-856$.
[5] Notoatmodjo, S. (2007). Promosi Kesehatan dan Ilmu Perilaku. Jakarta: Rineka Cipta.

[6] Moeloek, N. F. (2017). Indonesia National Health Policy in the Transition of Disease Burden and Health Insurance Coverage. Medical Journal of Indonesia, 26 (1), 3-6.

[7] Kemenkes R. I. (2017). Riset Kesehatan Dasar (RISKESDAS). Jakarta.

[8] Sugiyono. (2011). Metode Penelitian Kuantitatif Kualitatif dan R\&D. Bandung: Alfabeta.

[9] Riduwan. (2007). Skala Pengukuran Variabel-Variabel Penelitian. Bandung: Alfabeta.

[10] World Health Organization. (2017). Adolescent Health. Retrieved from https://www.who.int/website: https://www.who.int/health-topics/adolescent-health/\#tab=tab -1.

[11] Walgito, B. (2010). Pengantar Psikologi Umum (Revisi). Yogyakarta: CV. Andi Offset.

[12] Alamsyah, R. M. (2009). Faktor-Faktor yang Mempengaruhi Kebiasaan Merokok dan Hubungannya dengan Status Penyakit Periodontal Remaja di Kota Medan tahun 2007. Universitas Sumatera Utara.

[13] Ali, Z. (2019). Dasar-dasar Pendidikan Kesehatan Masyarakat dan Promosi Kesehatan. Jakarta: Trans Info Media. 